\title{
Nebivolol Reduces Proteinuria and Renal NADPH Oxidase-Generated Reactive Oxygen Species in the Transgenic Ren2 Rat
}

\author{
Adam Whaley-Connell ${ }^{a, b, d}$ Javad Habibi ${ }^{a, b, d}$ Megan Johnson ${ }^{a, b}$ \\ Roger Tilmon ${ }^{a, b} \quad$ Nathan Rehmer ${ }^{a, b}$ Jenna Rehmer ${ }^{a, b} \quad$ Charles Wiedmeyer ${ }^{c}$ \\ Carlos M. Ferrario ${ }^{\mathrm{e}}$ James R. Sowers ${ }^{a, b, d}$ \\ ${ }^{a}$ The University of Missouri School of Medicine, ${ }^{b}$ Diabetes and Cardiovascular Center, ${ }^{c}$ College of Veterinary \\ Medicine, ${ }^{\mathrm{d}}$ The Harry S. Truman VA Medical Center, Columbia, Mo., and ${ }^{\mathrm{e}}$ Hypertension and Vascular Disease \\ Center, Wake Forest University School of Medicine, Winston-Salem, N.C., USA
}

\section{Key Words}

Nebivolol $\cdot$ Proteinuria $\cdot$ NADPH oxidase $\cdot$ Reactive oxygen species

\begin{abstract}
Background/Aims: Renin-angiotensin-aldosterone system (RAAS) and sympathetic nervous system activation are crucial in the pathogenesis of hypertension, cardiovascular and renal disease. NADPH oxidase-mediated increases in reactive oxygen species (ROS) are an important mediator for RAAS-induced cardiovascular and renal injury. Increased levels of ROS can diminish the bioactivity of nitric oxide (NO), a critical modulator of RAAS effects on the kidney. Thereby, we hypothesized that in vivo nebivolol therapy in a rodent model of activated RAAS would attenuate glomerular damage and proteinuria through its actions to reduce NADPH oxidase activity/ROS and increase bioavailable NO. Methods: We utilized the transgenic Ren2 rat which displays heightened tissue RAAS, hypertension, and proteinuria. Ren2 rats (6-9 weeks of age) and age-matched SpragueDawley littermates were treated with nebivolol $10 \mathrm{mg} / \mathrm{kg} /$ day (osmotic mini-pump) for 21 days. Results: Ren2 rats exhibited increases in systolic blood pressure, proteinuria, kidney cortical tissue total NADPH oxidase activity and subunits
\end{abstract}

(Rac1, p67 ${ }^{\text {phox }}$, and p47 $7^{\text {phox }}$ ), ROS and 3-nitrotyrosine, as well as reductions in podocyte protein markers; each of these parameters improved with nebivolol treatment along with increases in renal endothelial NO synthase expression. Conclusions: Our data suggest that nebivolol improves proteinuria through reductions in renal RAAS-mediated increases in NADPH oxidase/ROS and increases in bioavailable NO.

Copyright $\odot 2009$ S. Karger AG, Basel

\section{Introduction}

Activation of the renin-angiotensin-aldosterone system (RAAS) and subsequent elevations of tissue angiotensin II and plasma aldosterone are crucial in the pathogenesis of hypertension, renal and cardiovascular disease [1-6]. Evidence suggests that reactive oxygen species (ROS) are an important mediator of adverse RAAS-induced renal and cardiovascular effects $[2,4,7]$. ROS are highly reactive molecules that oxidize lipids, cause cellular injury and promote glomerular and renal tubule injury and associated proteinuria. ROS promote uncoupling of endothelial nitric oxide (NO) synthase (eNOS) and thereby suppress activity of this enzyme with resul-

\section{KARGER}

(C) 2009 S. Karger AG, Basel

Fax +4161306 1234

E-Mail karger@karger.ch

www.karger.com
Accessible online at:

www.karger.com/ajn
Adam Whaley-Connell

University of Missouri-Columbia School of Medicine

Department of Internal Medicine, Division of Nephrology and Hypertension

CE417, DC043.0, Five, Hospital Dr., Columbia, MO 65212 (USA)

Tel. +1 573882 7992, Fax +1 573884 4820, E-Mail whaleyconnella@health.missouri.edu 
tant reductions in bioavailable NO [6]. Increased tissue levels of ROS can also diminish the bioactivity of NO by conversion of locally released $\mathrm{NO}$ to peroxynitrite $\left(\mathrm{ONOO}^{-}\right)$, which itself contributes to tissue injury [2, $4,7]$.

Bioavailable tissue NO appears to be a critical regulator of both RAAS and sympathetic nervous system (SNS) control of blood pressure and renal function [6-8]. Importantly, NO appears to counter-regulate the effects of both the SNS and RAAS in the renal regulation of salt and fluid homeostasis as well as renal injury $[6,7]$. Indeed, treatment strategies to increase bioavailable $\mathrm{NO}$ have been shown to protect against renal damage in several rodent models of RAAS and SNS-mediated renal sclerosis [9-13]. In this context, beta-blockers are known to suppress both the SNS and RAAS [14-19]. Nebivolol is a third-generation $\beta_{1}$-adrenergic blocker with distinct pharmacologic and pharmacodynamic properties compared with other agents in its class [16]. It is highly selective for cardiac $\beta_{1}$-adrenoceptors and lacks intrinsic sympathomimetic activity [14-18]. Additionally, nebivolol therapy promotes endothelium-dependent vasodilation through the L-arginine/NO pathway in different regional vascular beds $[14,15]$. Limited studies have shown that systemic treatment with this beta-blocker increases renal tissue levels of bioavailable $\mathrm{NO}$ and reduces renal fibrosis $[8,10,12,13]$. However, there have been very limited studies exploring the impact of nebivolol treatment on the kidney in animal models displaying glomerular injury and proteinuria.

Accordingly, we hypothesized that nebivolol, acting via its effect on $\mathrm{NO}$ and its antioxidant properties would have glomerular-protective and antiproteinuric effects in a scenario of increased renal RAAS and associated glomerular damage and proteinuria. To explore this hypothesis, we utilized the transgenic Ren2 rat which displays heightened tissue RAS and elevated plasma levels of mineralocorticoids, hypertension, glomerular injury and proteinuria [20-22]. We utilized a dose of nebivolol, demonstrated in preliminary work in our laboratory, to have minimal blood pressure-lowering effects in this transgenic model of enhanced RAAS and proteinuria.

\section{Methods}

\section{Animals and Treatments}

All animal procedures were approved by the University of Missouri animal care and use committees and housed in accordance with NIH guidelines. Transgenic TG(mRen2)27 (Ren2) rats (6-9 weeks of age) and age-matched Sprague-Dawley (SD) lit- termates were randomly assigned to control (sham-operated; Ren2-C and SD-C, respectively; $\mathrm{n}=6$ each), or nebivolol-treated (Ren2-A and SD-A, respectively; $\mathrm{n}=8$ each) treatment paradigms. Ren $2-\mathrm{N}$ and SD-N animals were treated with nebivolol $10 \mathrm{mg} / \mathrm{kg} /$ day released via an implanted osmotic mini-pump for 21 days.

\section{Systolic Blood Pressure and Proteinuria}

Restraint conditioning was initiated before blood pressure measurements were performed as previously described [3, 5]. Systolic blood pressure (SBP) was measured in triplicate on separate occasions throughout the day using the tail-cuff method (Student Oscillometric Recorder; Harvard Systems, Holliston, Mass., USA) prior to initiation of treatment and on days 19 or 20 prior to sacrifice at 21 days. Both creatinine and protein concentrations in urine were analyzed on an automated clinical chemistry analyzer (Olympus AU680, Olympus America Inc.; Centerville, Pa., USA) using commercial assays. Creatinine was determined using an automated Jaffe reaction assay and urine protein using an automated colorimetric assay. The chemistry instrument was calibrated and proper controls performed prior to analysis [20,22].

\section{NADPH Oxidase}

NADPH Oxidase Activity. NADPH oxidase activity was determined in kidney cortical tissue as previously described $[3,5,20]$. Briefly, NADPH oxidase activity was determined by measuring the conversion of radical detector (Cayman Chemical, Ann Arbor, Mich., USA) using spectrophotometric (450 nm) techniques.

NADPH Oxidase Subunit Immunostaining. Harvested kidney tissue was prepared as previously described [22]. Sections were incubated with 1:100 goat polyclonal p47 $7^{\text {phox }}$, p67 $7^{\text {phox }}$ (Santa Cruz Biotechnology, Santa Cruz, Calif., USA), and 1:200 Rac1 (primary antibodies; Upstate Cell, Cell Signalling, Millipore Corp.; Billeria, Mass., USA) in 10-fold diluted blocking agent overnight. After washing, the sections were incubated with 1:300 Alexa fluor donkey anti-goat 647 (Invitrogen, Invitrogen Corp.; Carlsbad, Calif., USA) for $\mathrm{p} 47^{\text {phox }}$ and $\mathrm{p} 67^{\text {phox }}$ Alexa fluor and donkey antimouse 647 for Racl for $4 \mathrm{~h}$. Then the slides were washed $(3 \times 15$ $\mathrm{min}$ ) and sections mounted with Mowiol and stored in light-tight slide boxes at $4^{\circ} \mathrm{C}$ until assessment using abi-photon confocal microscope (Zeiss LSM, Thornwood, N.Y., USA). 1,024 × 1,024 pixel images were captured with LSM imaging system under the same microscope and computer settings for all animals of four groups in each experiment. The signal intensities were measured and analyzed in the equal regions with MetaView as previously described [20-24].

\section{Oxidative Stress}

ROS Formation. This was measured by chemiluminescence as previously described [23]. Briefly, kidney tissue sections were homogenized in sucrose buffer using a glass/glass homogenizer, centrifuged, and supernatants (whole homogenate) were then removed and placed on ice. Whole homogenate $(100 \mu \mathrm{l})$ was added to $1.4 \mathrm{ml}$ of $50 \mathrm{mM}$ phosphate $\left(\mathrm{KH}_{2} \mathrm{PO}_{4}\right)$ buffer $(150 \mathrm{mM}$ sucrose, $1 \mathrm{mM}$ EGTA, $5 \mu \mathrm{M}$ lucigenin, $100 \mu \mathrm{M}$ NADPH, pH 7.0) in darkadapt counting vials. After dark adaptation, samples were counted on a luminometer and all counts were averaged. Samples were then normalized to total protein in the whole homogenate, and ROS values expressed as counts per minute per milligram of protein. 

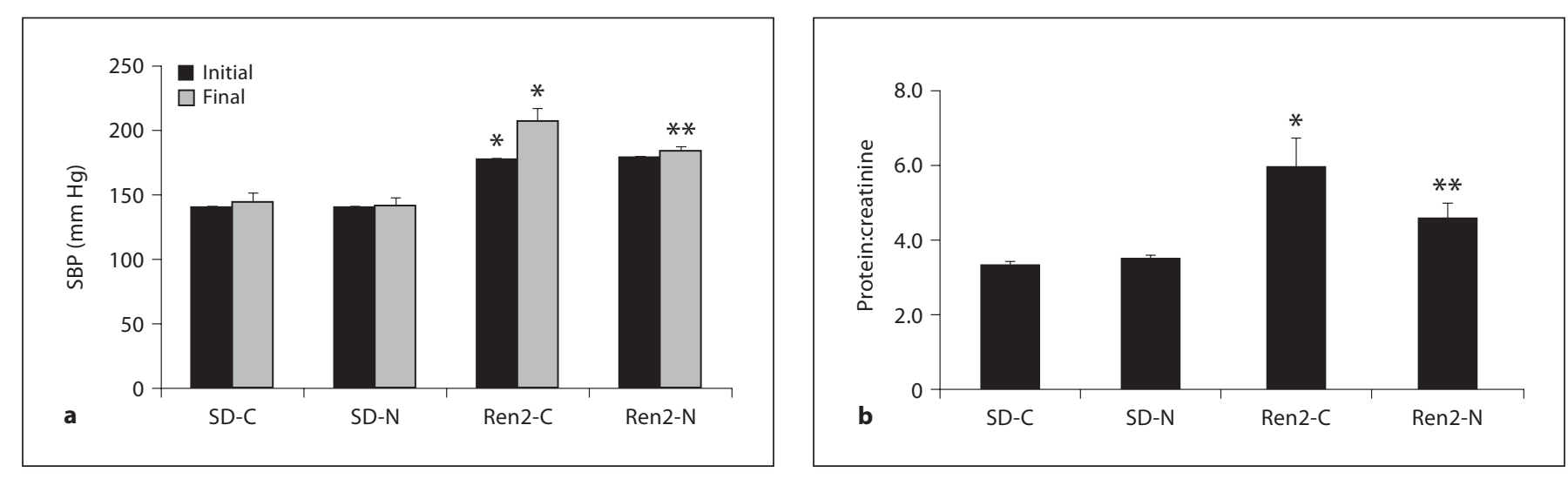

Fig. 1. Nebivolol reduced SBP and proteinuria in Ren2 rats. a SBP in Ren2 rats at the initiation and end of treatment period. b Proteinuria as determined by urine protein:creatinine ratio. ${ }^{*} \mathrm{p}<0.05$ vs. SD-C $(\mathrm{n}=5){ }^{* *} \mathrm{p}<$ 0.05 , Ren2-N ( $\mathrm{n}=8)$ vs. Ren2-C ( $\mathrm{n}=6)$.

\section{Immunohistochemistry for eNOS and Podocyte-Specific \\ Markers}

Four- $\mu \mathrm{m}$-sections of kidney were incubated with 1:50 mouse anti-eNOS III (BD Transduction Laboratories, San Jose, Calif., USA), 1:75 mouse monoclonal anti-desmin (Santa Cruz), and 1:75 rabbit polyclonal anti-podocin (Santa Cruz) overnight. The sections were incubated with appropriate secondary antibodies, mounted with Mowiol, and the images were captured and analyzed as described above.

Immunohistochemistry for 3-Nitrotyrosine

Briefly, kidney tissue samples were incubated with 1:150 primary rabbit polyclonal anti-nitrotyrosine antibody overnight (Chemicon, Temecula, Calif., USA). Sections were then washed and incubated with secondary antibodies, linked, and labeled with streptavidin for 30 min each. After several rinses with distilled water, diaminobenzidine was applied for $10 \mathrm{~min}$, sections again rinsed and stained with hematoxylin for $30 \mathrm{~s}$, rehydrated, and mounted with a permanent media. The slides were inspected under a bright-field (Nikon 50i, Tokyo, Japan) microscope and the $\times 40$ images captured with a Cool Snapcf camera.

\section{Statistical Analysis}

This investigation was powered based on prior sensitivity and variability measurements of albuminuria to achieve a significance of $\mathrm{p}<0.05$ with a power of 0.8 . All values are expressed as mean \pm standard error. Statistical analyses were performed in SPSS 13.0 (SPSS Inc., Chicago, Ill., USA) using ANOVA with Fisher's LSD as appropriate and Student's t test for paired analysis.

\section{Results}

\section{Nebivolol Reduced SBP and Proteinuria}

There were increases in initial and final SBP in the Ren 2 compared with SD controls $(177 \pm 7$ and $207 \pm 8$ $\mathrm{mm} \mathrm{Hg}$ vs. $141 \pm 9$ and $144 \pm 8 \mathrm{~mm} \mathrm{Hg}$, respectively; each $\mathrm{p}<0.05)$. At the end of the treatment period, administration of nebivolol resulted in SBP reductions in the Ren 2 compared with age-matched controls $(183 \pm 4 \mathrm{~mm}$ $\mathrm{Hg}, \mathrm{p}<0.05$; fig. 1$)$. Urine protein excretion was similarly increased in the Ren 2 when compared with SD controls $(5.96 \pm 0.79$ vs. $3.32 \pm 0.12 \mathrm{mg} / \mathrm{mg}, \mathrm{p}<0.05)$ and improved with nebivolol treatment $(4.59 \pm 0.39 \mathrm{mg} / \mathrm{mg}$, $\mathrm{p}<0.05)$.

\section{Nebivolol Reduced Renal NADPH Oxidase Activity}

As NADPH oxidase is the predominant source for renal oxidative stress, we sought to evaluate the effects of nebivolol on activity of this redox enzyme. Total NADPH oxidase enzyme activity was elevated in Ren2 compared with SD controls $(\mathrm{p}<0.05)$, and was normalized with nebivolol ( $p<0.05$; fig. $2 a$ ) to a value comparable to SD$\mathrm{C}$. There were similar increases in NADPH oxidase subunits Rac1, p47 $7^{\text {phox }}$, and p67 $7^{\text {phox }}$ in the Ren 2 when compared with SD controls ( $p<0.05$; fig. $2 b, c)$. Similar to total NADPH oxidase enzyme activity, there were reductions in all three critical subunits in nebivolol-treated Ren 2 renal cortical tissues $(\mathrm{p}<0.05)$.

\section{Nebivolol Improved Renal Oxidative Stress and eNOS}

To ascertain the effects of in vivo treatment with nebivolol on ex vivo kidney oxidative stress markers in the Ren2, we measured total ROS and 3-NT content as a marker for $\mathrm{ONOO}^{-}$formation in kidney cortical tissue. In parallel with increased NADPH oxidase activity, ROS levels were higher in Ren 2 controls compared with SD controls $(p<0.05)$ with a trend to improvements with nebivolol treatment ( $\mathrm{p}=0.08$; fig. $3 \mathrm{a}$ ). As previously re- 


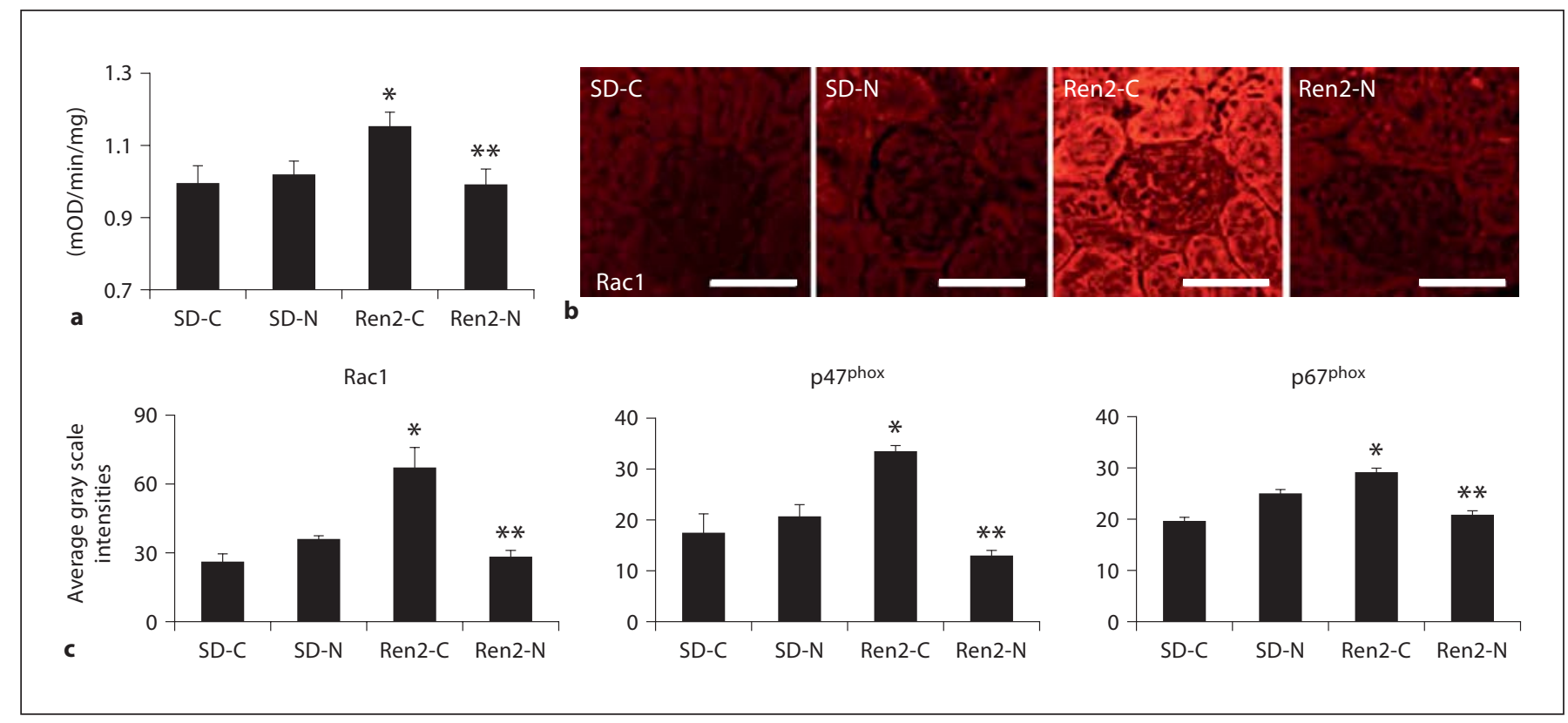

Fig. 2. Nebivolol reduced renal NADPH oxidase in Ren2 rats. a Total NADPH oxidase activity. b Representative images of semiquantitative immunohistochemistry analysis for NADPH oxidase subunit Racl. Scale bars $=50$ $\mu \mathrm{m}$. c Corresponding measures of intensity for Rac1, p47phox , and p67phox ${ }^{*} \mathrm{p}<0.05$ vs. SD-C $(n=6){ }^{* *} \mathrm{p}<$ 0.05 , Ren2-N ( $=8)$ vs. Ren2-C ( $=6)$.
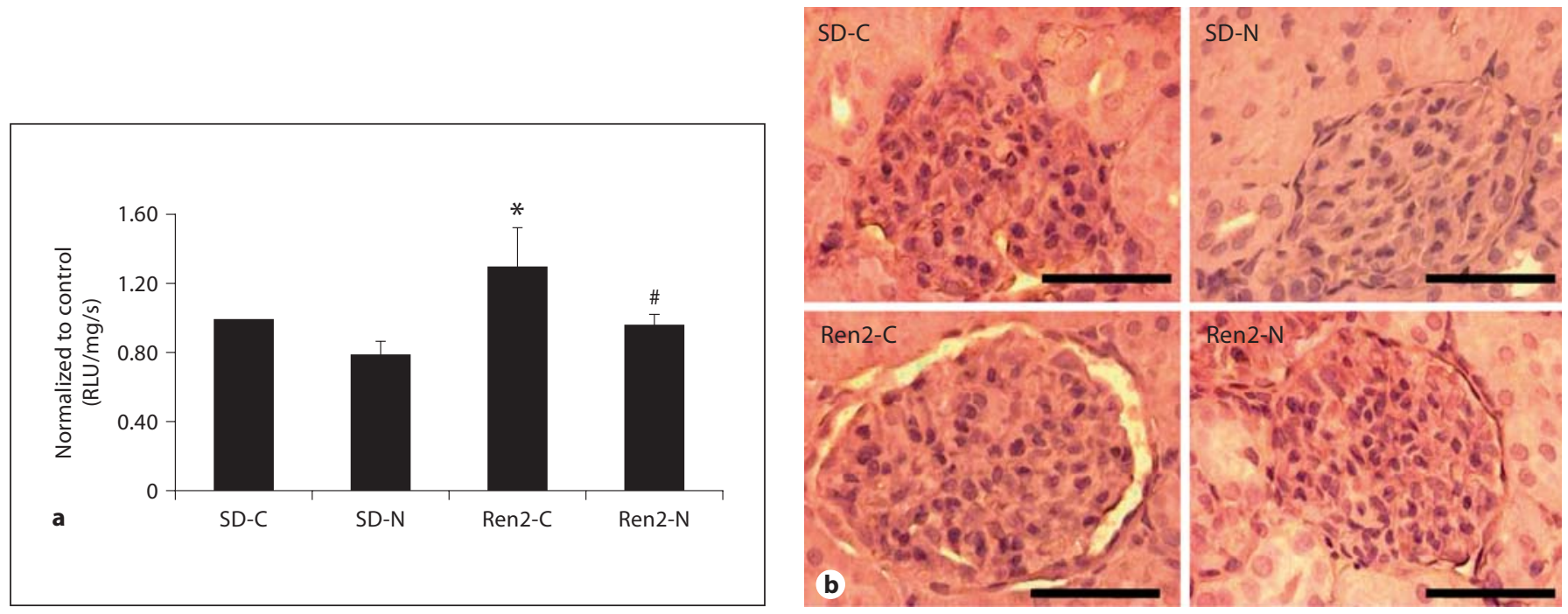

Fig. 3. Nebivolol improved renal oxidative stress in Ren 2 rats. a ROS formation by chemiluminescence. RLU = Relative light unit. b 3-Nitrotyrosine content as a marker of $\mathrm{ONOO}^{-}$formation. ${ }^{*} \mathrm{p}<0.05$ vs. SD-C $(\mathrm{n}=6)$; ${ }^{\#} \mathrm{p}=0.08, \operatorname{Ren} 2-\mathrm{N}(\mathrm{n}=8)$ vs. Ren2-C $(\mathrm{n}=6)$. Scale bars $=50 \mu \mathrm{m}$. 


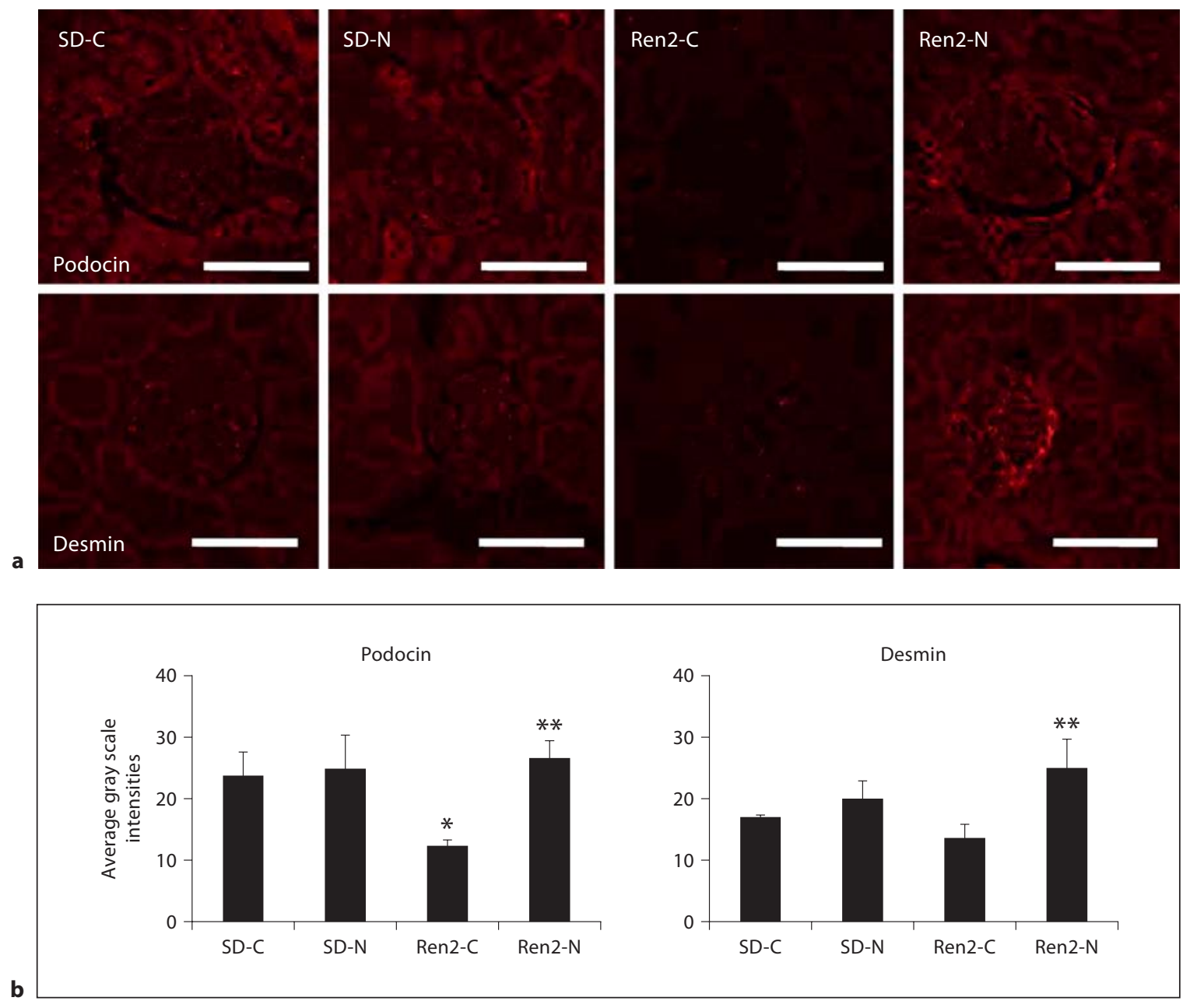

Fig. 4. Nebivolol improved podocyte-specific proteins in Ren2 rats. a Representative images of semiquantitative immunohistochemistry analysis for podocin, a podocyte-specific protein, and desmin, a cytoskeletal marker specific for the podocyte. Scale bars $=50 \mu \mathrm{m}$. $\mathbf{b}$ Corresponding measures of intensity. ${ }^{*} \mathrm{p}<0.05 \mathrm{vs}$. SD-C ( $\mathrm{n}=$ $6) ;{ }^{* *} \mathrm{p}<0.05, \operatorname{Ren} 2-\mathrm{N}(\mathrm{n}=8)$ vs. Ren2-C $(\mathrm{n}=6)$.

ported, 3-nitrotyrosine content in kidney cortical tissue is increased in the Ren 2 compared to SD controls [20, 24], and herein we report improvements with nebivolol treatment ( $\mathrm{p}<0.05$; fig. $3 \mathrm{~b}$ ). In parallel with the reductions in 3-NT, nebivolol treatment was also associated with increases in eNOS protein levels in Ren 2 and SD renal cortical tissue $\left(7.4 \pm 0.2 \times 10^{-4}\right.$ and $5.2 \pm 0.3 \times$ $10^{-4}$ average gray scale intensities, respectively) compared with age-matched controls $\left(2.3 \pm 0.8 \times 10^{-4}\right.$ and $2.9 \pm 0.1 \times 10^{-4}$ average gray scale intensities, respectively; each $\mathrm{p}<0.05)$, consistent with increased renal bioavailable NO.

\section{Nebivolol Improved Podocyte-Specific Protein}

Integrity in Ren 2 Rats

Consistent with glomerular damage, there was a significant reduction in the podocyte-specific protein podocin and a trend in the cytoskeletal podocyte marker desmin in Ren2 cortical tissue compared with SD as determined by semiquantitative immunohistochemical analyses $(12.1 \pm 1.3$ and $13.5 \pm 2.4$ vs. $23.7 \pm 3.8$ and $16.7 \pm 0.8$ average gray scale intensities, respectively). Levels of these podocyte proteins improved with nebivolol treatment in both the Ren 2 and SD compared with age-matched controls $(26.3 \pm 3.0$ and $24.8 \pm 4.8$ average gray scale intensities, each $\mathrm{p}<0.05$, respectively; fig. 4 ). 


\section{Discussion}

Results from this investigation support novel mechanisms by which nebivolol protects against glomerular injury and albuminuria in a transgenic rat model of RAAS activation. To our knowledge, this investigation is the first to demonstrate that nebivolol treatment results in reductions in proteinuria. Further, the improvements in proteinuria were observed in an animal model of RAAS activation that demonstrates hypertension, insulin resistance and proteinuria. Our findings underscore the potential importance that vasodilating beta-blockers have on reducing proteinuria. In this context, Bakris et al. [25] have demonstrated that treatment with carvedilol, another vasodilating beta-blocker, reduced albuminuria in patients with insulin resistance and the metabolic syndrome. Since nebivolol had modest effects on blood pressure in doses used in this transgenic model of proteinuria, we speculate that the beneficial effects in reducing proteinuria were related, in part, to other pharmacologic effects of this compound.

Nebivolol, unlike conventional beta-blockers, has been demonstrated to stimulate endothelial cell production of $\mathrm{NO}$ and to reduce NADPH oxidase activity in vascular tissue [26-28]. In those studies, treatment with nebivolol, but not metoprolol, normalized endothelial function, reduced vascular NADPH oxidase activity and subunits (Racl and p67 $^{\text {phox }}$ ) and NADPH oxidase-dependent superoxide formation and increased NO bioavailability. In the current investigation, nebivolol treatment was associated with reductions in renal Racl, p $47^{\text {phox }}$ and $\mathrm{p} 67^{\text {phox }}$ subunits necessary for NADPH oxidase activity $[1,6]$. Thus, this unique compound exerts similar effects on this redox enzyme in both the kidney and the vasculature. Results from the current investigation also indicate that in vivo treatment with nebivolol helps maintain the integrity of podocyte-specific proteins in concert with reduction in NADPH oxidase/ROS formation and increases eNOS levels in renal cortical tissue. These treatment effects of nebivolol in the transgenic Ren 2 rat occurred in concert with reductions in proteinuria.

Accumulating evidence supports the notion that activation of a tissue-based RAS promotes cell growth, metabolism, and tissue remodeling in the glomerulus [27]. Evidence for a local RAS in the glomerulus raises the prospect that NADPH oxidase/ROS-induced podocyte and filtration barrier injury may contribute to the development of proteinuria. Our data garnered in a rodent model of excessive RAAS activation further support the notion that RAAS activation of renal NADPH oxidase contributes to ROS formation, and decreased bioavailable NO occurs contemporaneously with glomerular podocyte injury and early proteinuria [20-22]. Indeed, our observation that reductions in the podocyte-specific proteins podocin and desmin, a marker for cytoskeletal integrity, are associated with increased ROS corroborates previous reports that the glomerular filtration barrier integrity is particularly susceptible to oxidative stress.

$\mathrm{ONOO}^{-}$is a highly reactive oxidant species that can be formed endogenously by the interaction of $\mathrm{NO}$ and superoxide anion, and this product reacts readily with tyrosine residues of proteins to form 3-NT $[29,30]$. This process contributes to a reduction in bioavailable $\mathrm{NO}$ and also indirectly to eNOS uncoupling, thereby further reducing bioavailable NO [6]. Reductions in NO and increases in ROS are thought to be the major causes of oxidative damage to lipids, proteins and DNA. Our results are also consistent with the notion that increases in $\mathrm{ONOO}^{-}$(measured as 3-NT) are highly reactive in the kidney and can contribute to glomerular/podocyte injury $[20-22,24]$. In addition, $\mathrm{ONOO}^{-}$has been shown to oxidatively deplete the essential eNOS cofactor, tetrahydrobiopterin, and result in eNOS uncoupling as another mechanism for reductions in bioavailable NO. Accordingly, we posit that nebivolol improves bioavailable $\mathrm{NO}$ through increases in eNOS production and reductions in destruction of this molecule in a rodent model of RAASmediated glomerular injury and proteinuria.

While the current investigation did not include a traditional beta-blocker as a control, collectively our data suggest that the improvements in proteinuria, despite the modest reductions in SBP, were likely associated with unique pharmacologic effects of this beta-blocker. Importantly, nebivolol treatment contributed to reductions in NADPH oxidase/ROS as well as increases in eNOS with subsequent improvements in podocyte-specific markers and proteinuria. There have been very limited studies exploring the effects of nebivolol treatment in states of proteinuria and glomerular injury. Our novel work extends previous limited work with this unique beta-blocker as it relates to renal tissue levels of bioavailable $\mathrm{NO}$ and reductions in renal disease $[8,10,12,13]$.

\section{Acknowledgements}

This research was supported by NIH R01 HL73101-01A1 to J.R.S., HL-51952 to C.M.F., and Veterans Affairs Merit System (0018) for J.R.S. and VISN 15 and CDA-2 for A.W.-C., and the Forest Research Institute. 


\section{References}

1 Griendling KK, Sorescu D, Ushio-Fukai M: NAD(P)H oxidase: role in cardiovascular biology and disease. Circ Res 2000;86:494501.

-2 Touyz RM: Reactive oxygen species, vascular oxidative stress, and redox signaling in hypertension: what is the clinical significance? Hypertension 2004;44:248-252.

$\checkmark 3$ Wei Y, Whaley-Connell AT, Chen K, Habibi J, Uptergrove GME, Clark SE, Stump CS, Ferrario CM, Sowers JR: NADPH oxidase contributes to vascular inflammation, insulin resistance, and remodeling in the transgenic (mRen2) rat. Hypertension 2007;50: 384-391.

4 Griendling KK, Murphy TJ, Alexander RW: Molecular biology of the renin-angiotensin system. Circulation 1993;87:1816-1828.

$\checkmark 5$ Whaley-Connell A, Govindarajan G, Habibi J, Hayden MR, Cooper SA, Wei Y, Ma L, Qazi M, Link D, Karuparthi PR, Stump C, Ferrario C, Sowers JR: Angiotensin II-mediated oxidative stress promotes myocardial tissue remodeling in the transgenic (mRen2) 27 Ren2 rat. Am J Physiol Endocrinol Metab 2007;293:E355-E363.

$\checkmark 6$ Cooper SA, Whaley-Connell A, Habibi J, Wei Y, Lastra G, Manrique C, Stas S, Sowers JR: Renin-angiotensin-aldosterone system and oxidative stress in cardiovascular insulin resistance. Am J Physiol Heart Circ Physiol 2007;293:H2009-H2023.

7 O’Donnell VB, Freeman BA: Interactions between nitric oxide and lipid oxidation pathways: implications for vascular disease. Circ Res 2001;88:12-21.

$\checkmark 8$ Kakoki M, Hirata Y, Hayakawa H, Suzuki E, Nagata D, Nishimatsu H, Kimura K, Goto A, Omata M: Effects of vasodilatory antihypertensive agents on endothelial dysfunction in rats with ischemic acute renal failure. Hypertens Res 2000;23:527-533.

9 Benigni A, Zoja C, Noris M, Corna D, Benedetti G, Bruzzi I, Todeschini M, Remuzzi G: Renoprotection by nitric oxide donor and lisinopril in the remnant kidney model. Am J Kidney Dis 1999;33:746-753.

10 Kalinowski L, Dobrucki LW, SzczepanskaKonkel M, Jankowski M, Martyniec L, Angielski S, Malinski T: Third-generation betablockers stimulate nitric oxide release from endothelial cells through ATP efflux: a novel mechanism for antihypertensive action. Circulation 2003;107:2747-2752.

$\checkmark 11$ Klahr S, Morrissey J: L-arginine as a therapeutic tool in kidney disease. Semin Nephrol 2004;24:389-394.
12 Georgescu A, Pluteanu F, Flonta ML, Badila E, Dorobantu M, Popov D: The cellular mechanisms involved in the vasodilator effect of nebivolol on the renal artery. Eur J Pharm 2005;508:159-166.

13 Pires MJ, Rodríguez-Peña AB, Arévalo M, Cenador B, Evangelista S, Esteller A, Sánchez-Rodríguez A, Colaço A, López-Novoa JM: Long-term nebivolol administration reduces renal fibrosis and prevents endothelial dysfunction in rats with hypertension induced by renal mass reduction. J Hypertens 2007;25:2486-2489.

14 Gupta S, Wright HM: Nebivolol: a highly selective beta1-adrenergic receptor blocker that causes vasodilation by increasing nitric oxide. Cardiovasc Ther 2008;26:189-202.

15 Fratta Pasini A, Garbin U, Nava MC, Stranieri C, Davoli A, Sawamura T, Lo Cascio V, Cominacini L: Nebivolol decreases oxidative stress in essential hypertensive patients and increases nitric oxide by reducing its oxidative inactivation. J Hypertens 2005;23:589596.

16 Van de Water A, Janssens W, Neuten JV, Xhonneux R, Cree JD, Verhaegen H: Pharmacological and hemodynamic profile of nebivolol, a chemically novel, potent, and selective beta 1-adrenergic antagonist. J Cardiovasc Pharmacol 1988;11:552-563.

17 Bowman AJ, Chen CP, Ford GA: Nitric oxide mediated venodilator effects of nebivolol. $\mathrm{Br}$ J Clin Pharmacol 1994;38:199-204.

18 Tzemos N, Lim PO, MacDonald TM: Nebivolol reverses endothelial dysfunction in essential hypertension: a randomized, doubleblind, crossover study. Circulation 2001;104: 511-514

19 Bristow MR, Nelson P, Minobe W, Johnson $\mathrm{C}$ : Characterization of [beta]1-adrenergic receptor selectivity of nebivolol and various other beta-blockers in human myocardium. Am J Hyperten 2005;18:A51-A52.

20 Whaley-Connell A, Habibi J, Nistala R, Cooper SA, Karuparthi PR, Hayden MR, Rehmer N, DeMarco VG, Andresen BT, Wei Y, Ferrario C, Sowers JR: Attenuation of angiotensin II-mediated NADPH oxidase activation and glomerular filtration barrier remodeling with statin treatment. Hypertension 2008;51:474-480.

21 Hayden MR, Whaley-Connell A, Sowers JR: Renal redox stress and remodeling in metabolic syndrome, type 2 diabetes mellitus, and diabetic nephropathy. Am J Nephrol 2005;25:553-569.
22 Whaley-Connell A, Chowdhury N, Hayden MR, Stump CS, Habibi J, Wiedmeyer C, Gallagher PE, Tallant A, Cooper SA, Link CD, Ferrario C, Sowers JR: Oxidative stress and glomerular filtration barrier injury: role of the renin-angiotensin system in the Ren2 transgenic rat. Am J Physiol Renal Physiol 2006;291:F1308-F1314.

23 Morris EM, Whaley-Connell A, Thyfault JP, Britton SL, Lock LG, Wei Y, Ibdah JI, Sowers JR: Low aerobic capacity and high fat diet contributes to oxidative stress and IRS-1 degradation in the kidney. Am J Nephrol 2008;30:112-119.

24 Whaley-Connell A, Habibi J, Wei Y, Gutweiler A, Jellison J, Wiedmeyer CE, Ferrario CM, Sowers JR: Mineralocorticoid receptor antagonism attenuates glomerular filtration barrier remodeling in the transgenic Ren2 rat. Am J Physiol Renal Physiol 2009;296: F1013-F1022.

25 Bakris GL, Fonseca V, Katholi RE, McGill JB, Messerli F, Phillips RA, Raskin P, Wright JT Jr, Waterhouse B, Lukas MA, Anderson KM, Bell DS; GEMINI Investigators: Differential effects of beta-blockers on albuminuria in patients with type 2 diabetes. Hypertension 2005;46:1309-1315.

-26 Oelze M, Daiber A, Brandes RP, Hortmann M, Wenzel P, Hink U, Schulz E, Mollnau H, von Sandersleben A, Kleschyov AL, Mülsch A, Li H, Förstermann U, Münzel T: Nebivolol inhibits superoxide formation by NADPH oxidase and endothelial dysfunction in angiotensin II-treated rats. Hypertension 2006; 48:677-684.

27 Mollnau H, Schulz E, Daiber A, Baldus S, Oelze M, August M, Wendt M, Walter U, Geiger C, Agrawal R, Kleschyov AL, Meinertz T, Münzel T: Nebivolol prevents vascular NOS III uncoupling in experimental hyperlipidemia and inhibits NADPH oxidase activity in inflammatory cells. Arterioscler Thromb Vasc Biol 2003;23:615-621.

28 Weber MA: The role of the new beta-blockers in treating cardiovascular disease. Am J Hypertens 2005;18:169S-176S.

29 Pacher P, Beckman JS, Liaudet L: Nitric oxide and peroxynitrite in health and disease. Physiol Rev 2007;87:315-424.

30 Nistala R, Whaley-Connell A, Sowers JR: Redox control of renal function and hypertension. Antioxid Redox Signal 2008;10:20472089. 